\title{
Can the Audit Committee Provide Better Oversight of Listed Companies? -An Efficiency of Cash Holdings Perspective
}

\author{
Cheng-Li Huang \\ Department of Accounting, Tamkang University
}

No.151, Yingzhuan Rd., Tamsui Dist., New Taipei City 25137, Taiwan (R.O.C.)

Tel: 886-2-2621-5656 ext.3368E-mail: chengli@ mail.tku.edu.tw

\author{
Wei-ju Chen \\ Department of Accounting, Tamkang University
}

No.151, Yingzhuan Rd., Tamsui Dist., New Taipei City 25137, Taiwan (R.O.C.)

Tel: 886-2-2621-5656 ext.3365E-mail:weiju@mail.tku.edu.tw

Kuo-Chen Lu (Corresponding author)

Graduate Institute of Management Sciences, Tamkang University

No.151, Yingzhuan Rd., Tamsui Dist.,New Taipei City 25137, Taiwan (R.O.C.)

Tel: 886-2-2658-5801 ext.2712E-mail: david.lu @ takming.edu.tw

Received: Feb. 20, 2016 Accepted: March22, $2016 \quad$ Published: June 1, 2016

doi:10.5296/ajfa.v8i1.9064 URL: http://dx.doi.org/10.5296/ajfa.v8i1.9064

\begin{abstract}
This study attempts to inspection the efficient of using cash holdings whether is improved after setting up audit committee sound corporate governance from the perspective of reducing agency costs. We use the difference in difference method to investigate the effect of oversight of audit committee from 2007 to 2010 the company with audit committee for sample. The empirical results show that the using efficiency of cash holdings isn't promoted after setting up audit committee with all listed companies sample. We further divided the sample into the




\section{Macrothink}

over-the-counter (OTC) market and the Taiwan Stock Exchange (TSE) market according to the stock market feather. The empirical indicated that the Taiwan Stock Exchange (TSE) market listed sample exhibited the effect of oversight of audit committee; however, the over-the-counter (OTC) market listed is not. It indicated that the different market structure did affect the effect of oversight of audit committee.

Keywords: Cash holdings, Corporate governance, Audit committee, Agency costs, Difference in difference method 


\section{Introduction}

The Sarbanes-Oxley Act of 2002 is a law legislated to strengthen the internal control of publicly listed firms and to specify the roles and responsibilities of audit committees in publicly listed firms. In Taiwan, all new listed firms have been required to adopt the independent director system since Feb, 2002. In an attempt to improve corporate governance, the legislature in Taiwan passed a major amendment to Securities and Exchange Act on Dec 20 , 2005. This amendment introduces the audit committee system to reinforce financial supervision. As to the independent director system, the authority has adopted a once-for-all policy, which requires all publicly listed firms to appoint independent directors before the end of 2017. To ensure the independence of their audit committee, the audit committee must be composed of only independent directors. This requirement is intended to prepare for full implementation of mandatory establishment of an audit committee. It is believed that after full implementation of this system, corporate governance in Taiwan will be completely different and more effective. According to Financial Supervisory Commission, the authority of publicly listed firms in Taiwan, the goal of this reform is to improve corporate governance, reduce occurrence of abnormal or illegal events in publicly listed firms, and progressively boost firm performance and investor confidence.

The audit committee system was first developed in the US to play an important role in corporate governance. In 1972, the Securities and Exchange Commission of the US issued Accounting Standard Release No. 123, titled 'Standing Audit Committees Composed of Outside Directors'. In 1977, the New York Stock Exchange (NYSE) adopted a requirement for all listed firms to establish an audit committee composed of independent directors before Jun 30, 1978. Meanwhile, American Stock Exchange (AMEX) also made the same suggestion to all listed firms. In 1987, National Association of Securities Dealers Automated Quotations (NASDAQ) passed a rule that requires all listed firms to set up an audit committee composed mainly of independent directors. Later, the audit committee system began increasingly prevalent across the capital markets in the US.

The corporate governance environment in the US has evolved to a very mature level. Effective corporate governance is contributive to higher firm performance, lower managerial risk, and better firmtransparency ${ }^{1}$. It is prescribed in the 2006 amendment to Taiwan's Securities and Exchange Act that all listed firms are required to adopt either the existing dual-track oversight system where both directors and supervisors are needed or the single-track oversight system where an audit committee is established. Firms which adopt the latter system are not required to appoint supervisors according to the Company Act (Article 14-4 of the Securities and Exchange Act). However, whether this system suits the financial environment and development of corporate governance in Taiwan and how implementation of this system will affect corporate governance of local firms is an issue worthy of long-term observation and research.

Previous research of the impact of audit committees focuses mainly on improvement in various dimensions from the perspective of earnings management, financial restatements, firm operation, and information transparency. Abbott and Parker (2000) find that the 
independence of audit committees and the frequency of meeting of committee members are negatively related to restatement of financial statements. Felo et al. (2003) show that having more experts with an accounting or financial background in the audit committee may be beneficial to the quality of financial reporting. The evidence in Hsu (2014) suggests that the presence of an audit committee can lead to a significant improvement in earnings quality.

The quality of working capital management is critical to a firm's performance. Cash is a type of asset that is easiest to acquire and control for firm managers. In this paper, we attempt to explore how the audit committee is related to the value of cash holdings and further examine if the audit committee can exert its oversight functions to reduce agency cost incurred by self-serving behavior of managers. Drawing upon a sample of firms which had established an audit committee during 2007-2010 and the value of cash holdings model developed by Faulkender and Wang (2006), we will perform a difference-in-differences analysis to investigate whether establishment of an audit committee can result in higher marginal value of cash holdings. In this analysis, differences between firms with and without an audit committee as well as differences before and after establishment of an audit committee will be examined. In contrast to previous research that focuses primarily on the accounting and financial aspects, we will discuss whether establishment of an audit committee can reduce agency cost and explore the effects in broader aspects from the corporate governance perspective. Our empirical evidence suggests that overall, publicly listed firms do not have a significant improvement in use efficiency of cash holdings after setting up an audit committee. In Taiwan, firms apply to go public in either the Taiwan Stock Exchange (TSE) or the over-the-counter (OTC) market. The amount of capital is the main differentiator between TSE-listed firms and OTC-listed firms. However, in addition to the amount of capital, TSE-listed firms and OTC-listed firms also differ greatly in firm size, ratio of institutional investors, and stock liquidity. Therefore, we further divide the sample by market into the TSE-listed group and the OTC-listed group for further analysis. Our finding from TSE-listed firms shows that the value of cash holdings increases after establishment of an audit committee. This finding suggests that the audit committee can effectively exert its oversight functions in TSE-listed firms. Our finding from OTC-listed firms shows that the value of cash holdings declines after establishment of an audit committee. This finding implies that firms with lower stock liquidity attract relatively less attention from investors, and their managers are therefore less motivated to fairly report the firm's financial information to facilitate oversight by shareholders. In addition, these firms are smaller in size, so the cost of complying with the audit committee system is higher for them. As a result, for OTC-listed firms, the adverse effects of setting up an audit committee often come before the benefits of doing it.

The remainder of this paper is as follows: Section 2 reviews related literature and presents hypotheses. Section 3 explains the methodology, including the empirical model, variable measurement, and sampling method. Section 4 presents the analysis results, and Section 5 concludes findings of this paper. 


\section{Literature review and hypotheses development}

\subsection{The benefits of setting up an audit committee}

Basically, the primary purpose of an audit committee is to provide oversight of the financial reporting process, the self-discipline, and the effectiveness of internal controls of the firm. An audit committee is mainly composed of independent directors. Independence is vital to its functions in the firm. Bedard et al. (2004) use the ratio of independent directors in the audit committee as a measure of independence of the committee and find a negative relation between the ratio and occurrence of restatement of financial statements. Abbott et al. (2003) show that the independence and frequency of meeting of the audit committee are negatively related to restatement of financial statements to the level of significance.

The presence of an audit committee can increase oversight of financial statements, leading to higher accrual quality and less earnings management. Hsu (2014) explores the improvement in earnings quality among firms that have switched from the supervisor system to the audit committee system. It is empirically found that firms tend to have improved earnings quality and pay more attention to shareholder equity after adopting the audit committee system. Wild (1996) points out that investors have greater trust in a firm's financial statements if the firm has set up an audit committee. This suggests that an audit committee can improve a firm's financial reporting quality. According to the signaling theory (Grossman, 1981; Milgrom, 1981; Verrecchia, 1983), managers disclose favorable information concerning their firm performance when they learn that their firm value exceeds market expectation. This positive signal can usually cause a rise of the firm's stock price. Therefore, it can be inferred that when a firm discloses information regarding its establishment of an audit committee, investors will also show higher trust in the firm's financial reporting processes, and their increased trust will be reflected upon the firm's stock price.

As to the expertise of audit committee members, Cohen et al. (2014) point out that audit committee members who are both accounting and industry experts perform better than those with only accounting expertise. Besides, they find that audit committee members often increase audit fees to provide more assurance on the quality of the financial reports.

\subsection{Theories and literature on cash holdings}

The concept of cash holding was first mentioned in Keynes' (1936) liquidity preference theory, which identifies three motives behind the desire to hold cash: (1) transaction motive, precautionary motive, and speculative motive. Under these motives, how much cash is held and how the cash is used are important financial decisions for firms in management and value creation. However, due to the high liquidity nature, cash is often used by managers as a means of manipulation or as a means to fulfill personal interests. Jensen and Meckling (1976) identify the agency problem caused by free cash flow. They suggest that self-serving managers may waste firm resources on personal interests or enjoyment or invest cash holdings in negative net present value projects, and either of which behaviors will do harm to shareholder interest. According to Myers and Rajan (1998), it is easier for managers to turn liquid assets into private benefits at a lower cost compared to fixed assets. The greater the 
amount of liquid assets is available, the more likely that a serious agency problem will occur. Hence, the value of cash held by a firm can be used to explain whether the firm's resources have been inefficiently used by its managers for personal interests.

Pinkowitz et al. (2006) point out that due to the agency cost, the marginal value of a dollar is lower than a dollar, and the short part is expropriated for personal interests. They also find that the marginal value of a dollar cash is lower in countries with poor corporate governance than in countries with good corporate governance. Dittmar and Mahrt-Smith (2007) investigate how corporate governance affects firm value through cash holdings among firms with good governance and firms without. They find that poorly governed firms dissipate excess cash quickly and therefore suffer lower performance. They suggest that cash is easy to manage, less monitored, and flexible for use. Hence, managers tend to waste firm resources on the pursuit of personal interests. Their empirical finding indicates that the value of a dollar cash ranges between 0.42 0.88 in poorly governed firms, and the value of a dollar cash is approximately two times this value in firms with good governance.

\subsection{Hypotheses}

Previous research suggests that the presence of an audit committee can improve earnings quality and reduce earnings management. Because the audit committee provides oversight of financial reporting processes, investors show greater trust in the reliability of financial reports prepared by firms with an audit committee, and their trust will be reflected on the firm's stock price. Previous research of cash holdings suggests that firm managers may take advantage of the high liquidity of cash to fulfill personal interests at the expense of shareholder interest, and the efficiency of cash holdings is often higher in well governed firms than in poorly governed firms. The audit committee plays an important role in corporate governance. If the committee effectively exerts its functions, it can help a firm improve its overall performance and governance, reduce its agency cost, and increase the value of its cash holdings. Therefore, we propose the following hypothesis:

H1: The presence of an audit committee can improve the marginal value of cash holdings.

In Taiwan, firms stocks can be traded in the exchange market or the over-the-counter market. Firms whose stocks are traded in the exchange market are called TSE-listed firms, and firms whose stocks are traded in the over-the-counter market are called OTC-listed firms. In this study, we attempt to explore the effect of the audit committee on the value of cash holdings. As the two markets are structurally different, we will further divide the sample into the TSE-listed group and the OTC-listed group to examine if the above-mentioned effect differs between the two markets. We will consider three major structural differences between the two markets, including investor structure, market liquidity, and firm size.

For firms planning to go public, the requirements for the TSE market are higher. To be eligible for being listed in the TSE market, firms need to meet a higher capital and a higher profitability requirements. The OTC market is intended to facilitate development of small and medium-sized enterprises and thus has lower requirements for applicants. Firms with an actual paid-in capital exceeding NT\$50 million and having innovation or development 
potentials are eligible to become an OTC-listed firm. Hence, small capital stock is a major characteristic of OTC-listed firms.

The OTC market was created in 1994. After a series of reforms of the trading system, there has been a significant growth in the number of OTC-listed firms, accounts, and trading volume. Despite the dominance of individual investors in this market, the number of institutional investors is increasing year by year. Chui and Wei (1998) compare the stock markets in Hong Kong, South Korea, Malaysia, Thailand, and Taiwan and find that individual investors favor small-cap stocks while institutional investors tend to invest in large-cap stocks. The efficient monitoring hypothesis posited by Pound (1988) suggests that institutional investors have more specialized human resources and are therefore more able to efficiently monitor the firms they invest in. Huang et al. (2014) contend that external supervision is mainly performed by institutional investors, so the effect of information disclosure on corporate governance is stronger in markets dominated by institutional investors. According to Taiwan Stock Exchange (TSE) and GreTai Securities Market (GTSM), the ratios of individual investors in the TSE market and the OTC market as of 2010 are $58.54 \%$ and $67.68 \%$ respectively $^{2}$. The OTC market has an approximately $10 \%$ higher ratio. Individual investors have a limited ability and time to collect and analyze data, so the effect of the audit committee on the value of cash holdings may be smaller in the OTC market. Thus, we infer that the relation between the presence of audit committee and the value of cash holdings is weaker in the OTC market that is dominated by individual investors.

In addition to investor structure, the two markets also differ greatly in liquidity. According to TSE and GTSM, the turnover rates in the two markets as of 2010 are 1.44 and 1.31 respectively ${ }^{3}$. By comparison, the OTC market has a lower liquidity. In a study of liquidity of the stock markets in Taiwan, Huang (2013) finds that the TSE market has a significantly higher liquidity than the OTC market. According to Bernstein (1987) and Hasbrouck and Schwartz (1988), liquidity is a measure of how promptly that securities can be traded in a market or how minimal the market prices will be affected by the trading. It has been empirically confirmed in many studies that market size is positively related to liquidity (Fraser and Groth, 1985; Cooper et al., 1985; Marsh and Rock, 1986; Hasbrouck and Schwartz, 1988). Naidu and Rozeff (1994) argue that stock prices are more volatile in a market with lower liquidity. In this kind of market, the trading cost for investors is higher, and there is a weaker incentive for firms to provide financial information. As a result, investors will demand higher returns to compensate for these unfavorable conditions, and the capital cost for firms in this market will be higher. In other words, the capital cost is lower in market with higher liquidity. Fang et al. (2009) show a positive relation between stock liquidity and firm value. From firms' point of view, higher stock liquidity means lower rate of return expected by investors. Increasing stock liquidity is therefore a way for them to reduce capital cost and increase firm value. Besides, Maug (1998) investigates the relationship between stock liquidity and firm governance using a self-developed model and finds that liquidity provides an incentive for large shareholders to monitor public corporations and their increased oversight will lead to better governance of the corporations. Ball et al. (2000) state that the effectiveness of corporate governance mechanisms depends on whether financial 
information is reported in a fair way that allows shareholders to exert their oversight and secure their interest. Markets with lower liquidity or a lower ratio of institutional investors receive less attention from investors, so information asymmetry is usually higher in this kind of markets. High information asymmetry will weaken external oversight and the positive effect of corporate governance on the use efficiency of cash holdings.

Last but not least, firm size is also a key difference between the TSE market and the OTC market. The TSE market requires firms to have an actual paid-in capital exceeding NT $\$ 600$ million, while the OTC market requires only a minimum of NT\$50 million. Studies have shown that some of the authority's control mechanisms have different effects on firms of different sizes. Since the end of 2001, many financial scandals in the US have been reported. In order to recover investors' confidence in public corporations, the US Congress passed SOX in 2002 in a relatively prompt manner. SOX prescribes that all public corporations shall set up an audit committee. After this law went into effect, all firms whose stocks are traded in any capital market (including the OTC market) must comply with this new requirement. It should be noted that SOX does not have different regulations for firms of different sizes. As a result, since implementation, this law has incurred a huge compliance $\operatorname{cost}^{4}$ to a portion of small companies. The compliance cost includes the cost of additional human resources, the cost of consulting, the cost of information technology, and additional audit fees. Holmstrom and Kaplan (2003) mention that this compliance cost is a heavy burden for small firms. In order to avoid the complicated procedures and the high cost of complying with SOX requirements, small firms in the US are inclined to reduce the amount of its outstanding shares or directly apply for withdrawal from the market (Akhigbe and Martin, 2006; Block, 2004; Koehn and Del Vecehio, 2004; Mount, 2005).

According to Blundell and Robinson (2000), the total compliance cost of federal regulations for public firms in the US is around US\$700 billion, about 30 times the cost of all the administrative agencies in the US. Spence (2001) points out that small and medium-sized firms suffer a greater deficiency of resources for coping with this cost compared to large ones. Chittenden et al. $(2002 ; 2003)$ survey the compliance cost for firms in the US, UK, Australia, and New Zealand. Their finding confirms that the compliance cost is higher for small firms than for large ones. Michaelis et al. (2001) show that small and medium-sized companies need to spend $30 \%$ more time on administrative tasks and a $20 \%$ more labor cost to meet the requirements of related regulations compared to large firms. Bull and Sharp (1989) mention that firms must bear a certain cost to have independent directors or set up an audit committee. From the economic efficiency perspective, the cost can bring more benefits to larger firms. DiGabriele (2008) finds that since implementation of SOX, nonpublic firms have suffered a significant increase in loss of firm value.

Menon and Williams (1994) show that firms with a larger board can benefit more from setting up an audit committee. Besides, larger firms are harder to monitor, so the presence of an audit committee is more essential for larger firms. Abbott et al. (2003) argue that although the audit committee can help increase the reliability of financial statements, the higher audit assurance it demands will increase the audit fees. In Taiwan, TSE-listed firms are significantly larger than OTC-listed firms. Larger firms are more capable to afford all the 
costs of an audit committee. Therefore, the benefits of setting up an audit committee are certainly more pronounced in larger firms. OTC-listed firms are smaller in nature. In addition to the necessity, they need to consider the costs and benefits of an audit committee. If the costs exceed the benefits, setting up an audit committee may contrarily reduce their overall performance.

In summary, the TSE market has a higher ratio of institutional investors than the OTC market. The effect of setting up an audit committee on the value of cash holdings may be weaker in the OTC market that is dominated by individual investors. In terms of stock liquidity, the liquidity is higher in the TSE market than in the OTC market. In a less liquid market, investors pay less attention to financial information disclosed by firms. Since external oversight is weak, the presence of an audit committee alone cannot help reflect the effect of higher efficiency of cash holdings on stork returns. Besides, compared to TSE-listed firms, OTC-listed firms are smaller in size. As mentioned above, the compliance cost will be higher for OTC-listed firms. We argue that the high compliance cost will mitigate the increase in the value of cash holdings resulting from setting up an audit committee. Based on the above discussion, we propose the following hypothesis:

$\mathrm{H} 2$ : The presence of an audit committee can generate a higher increase in the marginal value of cash holdings for TSE-listed firms than for OTC-listed ones.

\section{Method}

\subsection{Sample composition}

The sample consists of TSE-listed firms and OTC-listed firms. Article 14-4 of the Securities and Exchange Act prescribes that all public firms shall establish either an audit committee or a supervisor starting in Jan 1, 2007. Our sample period is between 2007 and 2010. Excluding foreign firms that went public in Taiwan, a total of 31 firms do not have data before establishment of an audit committee for comparison. The final sample consists of 28 firms. Of these firms, 16 are TSE-listed and 12 are OTC-listed. In terms of distribution of industries, most firms are from the electronics industry (86\%). In terms of intention to establish an audit committee, approximately $86 \%$ of the firms set up an audit committee voluntarily.

The purpose of this study is to investigate whether the improvement in firm value contributed by one unit of cash holdings after setting up an audit committee is greater than the improvement before setting up an audit committee. We define the period from the year when an audit committee is established to the end of the next year as the post-establishment period, and the two-year period prior to establishment of the committee as the pre-establishment period. For instance, if a firm establishes an audit committee in 2007, its post-establishment period is between 2007 and 2008, and its pre-establishment period is between 2005 and 2006. Hence, our observations span from 2005 to 2011. Each sample firm has data across four years. From 28 sample firms, we collect a total of 112 observations.

In addition to differences between the pre-establishment period and the post-establishment period, we also analyze differences between firms with an audit committee and firms without. Thus, we adopt the difference-in-differences method. In this method, we classify firms with 
an audit committee into the treatment group and firms without into the control group. To avoid the effect of a large size difference between the two groups, we adopt a pairing approach which involves choosing one firm for each firm in the treatment group. To build the paired sample, we have to select firms which have not set up an audit committee during 2007 2010. Market, industry, and firm size are all considered in the selection process, and firm size is measured by the market value of equity. Each sample firm has a different paired firm in each year. For the 28 sample firms over the four-year period from 2007 to 2010, we select a total of 112 paired firms without an audit committee.

The data of firms with an audit committee are extracted from 'The summary of firms that have established an audit committee according to Article 14-4 of the Securities and Exchange Act' published in the corporate governance section of Market Observation Post System set up by TSE. The financial data of these firms are obtained from Taiwan Economic Journal (TEJ). The sample selection process, market distribution and industry distribution of the sample firms, and their intention to set up an audit committee are detailed in Table 1.

Table 1.Sample composition

\begin{tabular}{lccccc}
\hline Panel A: Sample selection & 2007 & 2008 & 2009 & 2010 & Total \\
\hline Having an audit committee & 11 & 17 & 12 & 27 & 67 \\
$\begin{array}{l}\text { Financial and insurance } \\
\text { industry }\end{array}$ & -2 & -4 & -2 & 0 & -8 \\
$\begin{array}{l}\text { Missing data of market } \\
\text { value or returns }\end{array}$ & -2 & -2 & -5 & -22 & -31 \\
\hline Total & 7 & 11 & 5 & 5 & 28 \\
\hline Panel B: Market type & 6 & 5 & 2 & 3 & 16 \\
TSE & 1 & 6 & 3 & 2 & 12 \\
OTC & 7 & 11 & 5 & 5 & 28 \\
\hline Total & & & & & \\
\hline Panel C: Industry & 0 & 0 & 0 & 1 & 1 \\
Chemical and bioengineerin & 0 & 1 & 0 & 0 & 1 \\
Steel & 6 & 10 & 4 & 4 & 24 \\
Electronics & 0 & 0 & 1 & 0 & 1 \\
Construction & 1 & 0 & 0 & 0 & 1 \\
Others & 7 & 11 & 5 & 5 & 28 \\
\hline Total & 2 & 1 & 1 & 0 & 4 \\
\hline Panel D: Implementation type & 5 & 10 & 4 & 5 & 24 \\
Mandatory & 7 & 11 & 5 & 5 & 28 \\
Non-mandatory & & &
\end{tabular}

\subsection{Definition of variables}

\subsubsection{Explained variable}

In our empirical model, the explained variable is abnormal return $\left(r_{i, t}-R_{i, t}^{B}\right)$. It is defined as the difference between the actual return of a stock and the benchmark return. The benchmark 
return is the return of a portfolio of stocks with similar size and book-to-market characteristics (Fama and French 1993). Fama and French (1993) argue that a model consisting of a market factor, a risk factor related to size, and a risk factor related to book-to-market can better explain market returns. Moreover, this kind of model can explain risk factors that $\beta$ in CAPM cannot capture. In this paper, we adopt Fama and French's (1993) three-factor model to estimate abnormal return. In this model, $r_{i, t}$ is the actual return

of firm i over year $\mathrm{t}$, and $R_{i, t}^{B}$ is the benchmark return for firm i over year $\mathrm{t}$. We sort all the firms by market value and book-to-market ratio (BE/ME) in ascending order and divide them into five groups by each index. By doing so, we can obtain a total of 25 combinations of size and book-to-market ratio. $R_{i, t}^{B}$ is the return of a portfolio of stocks to which firm i belongs over year t. Finally, we compute the difference between the actual return and the benchmark return to obtain the abnormal return of each firm.

\subsubsection{Explanatory variables}

$\Delta C_{i, t}$ is the change in cash and cash equivalent over year $t$, and $M_{i, t-1}$ is the market value of equity at the end of year $t-1$. The focus of our analysis is to find the effect of change in each unit of cash on equity value. The variations of stock returns are mainly between $M_{i, t}$ and $M_{i, t-1}$, so we use $M_{i, t-1}$ as the basis for shifting.This allows us to eliminate size differences and use the marginal value to estimate the coefficients.

\subsubsection{Moderator variables}

Post-establishment of an audit committee $\left(P O S T_{i, t}\right)$ : This is a dummy variable. 1 denotes the year when an audit committee is established and the following year; 0 denotes the two-year periodprior to establishment of an audit committee. This variable is used to observe if there is a significant difference in efficiency of cash holdings before and after an audit committee is established.

Presence of an audit committee $\left(A C_{i, t}\right)$ :This variable is also a dummy variable. If an audit committee has been established, this variable is 1 ; if otherwise, this variable is 0 . This variable is a differentiator between paired firms (control group) and sample firms (treatment group).

\subsubsection{Control variables}

The control variables are mainly variables related to firm characteristics. In the financial dimension, the variables include change in interest expense $\left(\Delta I_{i, t}\right)$, change in dividends on common shares $\left(\Delta D_{i, t}\right)$, and change in net financing $\left(N_{i, t}\right)$, which is the total equity issuance minus repurchases plus debt issuance minus redemption. In the earnings dimension, the variables include earnings before extraordinary items and interest $\left(\Delta E_{i, t}\right)$, change in total assets minus cash and cash equivalents $\left(\Delta N A_{i, t}\right)$, and change in research and development expense $\left(\Delta R D_{i, t}\right)$. Other control variables include cash and cash equivalent in the previous year $\left(C_{i, t-1}\right)$ and leverage $\left(L_{i, t}\right)$. As our observations span six years from 2005 to 2011, we use six dummy variables of year to control the effect of year. Besides, the industry of each 
sample is determined according to TEJ's classification. As shown in Table 5, we classify the sample firms into five major industries. Hence, we use four dummy variables of industry. The operational definition of each variable is provided in Table 2.

Table 2. Definition of variables

\begin{tabular}{|c|c|}
\hline Variable & Operational definition \\
\hline$r_{t}-R_{t}^{B}$ & $\begin{array}{l}\text { It is defined as the difference between the actual return of a stock and the benchmark } \\
\text { return. } \mathrm{r}_{\mathrm{t}} \text { is the actual return of stock of firm } i \text { over year } t \text {. The benchmark return is the } \\
\text { return of a portfolio of stocks with similar size and book-to-market characteristics } \\
\text { (Fama and French, 1993). We sort all the listed firms by market value and } \\
\text { book-to-market ratio (BE/ME) in ascending order and divide them into five groups by } \\
\text { each index. By doing so, we can obtain a total of } 25 \text { combinations of size and } \\
\text { book-to-market ratio. } R_{i, t}^{B} \text { is the return of a portfolio of stocks to which firm } i \text { belongs } \\
\text { over year } t \text {. }\end{array}$ \\
\hline$\Delta C_{t}$ & $\begin{array}{l}\text { Change in cash and cash equivalent from } t-1 \text { to } t \text { divided by the lagged market value of } \\
\text { equity }\end{array}$ \\
\hline$A C_{t}$ & If the firm has an audit committee, this variable is 1 ; if otherwise, this variable is 0 . \\
\hline $\mathrm{POST}_{t}$ & $\begin{array}{l}1 \text { denotes the year when an audit committee is established and the following year, and } \\
0 \text { denotes other periods of time. }\end{array}$ \\
\hline$\Delta E_{t}$ & $\begin{array}{l}\text { Change in earnings before extraordinary items and interest divided by the lagged } \\
\text { market value of equity }\end{array}$ \\
\hline$\Delta N A_{t}$ & $\begin{array}{l}\text { Change in total assets minus cash and cash equivalents divided by the lagged market } \\
\text { value of equity }\end{array}$ \\
\hline$\Delta R D_{t}$ & $\begin{array}{l}\text { Change in research and development expense divided by the lagged market value of } \\
\text { equity }\end{array}$ \\
\hline$\Delta I_{t}$ & Change in interest expense divided by the lagged market value of equity \\
\hline$\Delta D_{t}$ & Change in dividends on common shares divided by the lagged market value of equity \\
\hline$C_{t-1}$ & Cash and cash equivalents at $t-1$ divided by the lagged market value of equity \\
\hline$L_{t}$ & The ratio of total debts to the sum of market value of equities and total debts \\
\hline$N F_{t}$ & $\begin{array}{l}\text { The total equity issuance minus repurchases plus debt issuance minus debt redemption } \\
\text { divided by the lagged market value of equity }\end{array}$ \\
\hline$M_{t-1}$ & Market value of the firm over year $t-1$ \\
\hline
\end{tabular}

\subsection{Empirical model}

We extend the value model of cash holdings developed by Faulkender and Wang (2006) as shown in Equation (1) to investigate whether the relation between abnormal return $\left(r_{i, t}-R_{i, t}^{B}\right)$ and change in cash $\left(\Delta C_{i, t}\right)$ varies significantly after establishment of an audit committee. If the effect of agency cost is controlled for, each additional dollar held can bring a proportional amount of price return to the firm. We extend Faulkender and Wang's (2006) model by 
including a few extra variables. One of them is a product term of post-establishment of an audit committee $\left(P O S T_{i, t}\right)$ and change in cash. This variable is used to examine whether the marginal value of each dollar rises after establishment of an audit committee, that is, whether setting up an audit committee can lead to a reduction of agency cost. To control the effect of industry on stock returns, we also include the fixed effects of industry. $\delta_{13}$ is a focus variable in this empirical model. A significantly positive value of this coefficient suggests a rise in the value of cash holdings after establishment of an audit committee. It can offer preliminary evidence that setting up an audit committee contributes to reduction of agency costs.

$$
\begin{array}{r}
r_{i, t}-R_{i, t}^{B}=\delta_{0}+\delta_{1} \Delta C_{i, t}+\delta_{2} P_{O S T} T_{i, t}+\delta_{3} \Delta E_{i, t}+\delta_{4} \Delta N A_{i, t}+\delta_{5} \Delta R D_{i, t}+\delta_{6} \Delta I_{i, t}+\delta_{7} \Delta D_{i, t}+\delta_{8} C_{i, t-1}+ \\
\delta_{9} L_{i, t}+\delta_{10} N F_{i, t}+\delta_{11} C_{i, t-1} * \Delta C_{i, t}+\delta_{12} L_{i, t} * \Delta C_{i, t}+\delta_{13} P O S T_{i, t} * \Delta C_{i, t}+\text { pyearfixedeffects }+ \\
\varphi_{1} \text { industryfixedeffects }+\mu_{i, t}(1)
\end{array}
$$

We attempt to capture differences in the value of cash holdings before and after establishment of an audit committee. However, the differences may be a common tendency among all the firms over time and not contributed by the audit committee. To control the effect of temporal trends, we use the DID method, which is extensively used in various areas of research to observe the effect of an event or policy. To use this method, we divide the sample into the treatment group and the control group and classify firm data by the time of establishment of an audit committee into pre-establishment and post-establishment. Hence, the cross-sectional differences between the two groups and differences between pre-establishment and post-establishment can be compared. As the effects of permanent, unobservable differences and temporal trends can be simultaneously controlled for, the effect of a particular event can be captured. In this study, firms with an audit committee are classified into the treatment group, and firms without are classified into the control group. We apply the DID method to test if the marginal value of cash holdings significantly improves due to establishment of an audit committee. In the test, $A C_{i, t}$ is used to differentiate the treatment group and the control group. Using Equation (1) as a basic model, we further consider AC, the product term of AC and change in cash, the product term of AC and POST, and the product term of AC, POST, and change in cash to create Equation (2) where $\delta_{14}$ is the difference in the value of cash holdings in firms without an audit committee before and after their paired firms set up an audit committee; $\delta_{16}$ is the difference in value of cash holdings in firms with an audit committee compared to firms without an audit committee during the pre-establishment period; $\delta_{17}$ is the difference in value of cash holdings after establishment of an audit committee among firms with an audit committee minus the difference in the value of cash holdings after establishment of an audit committee among firms without an audit committee. $\delta_{17}$ is a variable of our primary interest. If it is significantly positive, we can infer that setting up an audit committee can lead to a higher value of cash holdings after the effects of permanent, unobservable differences and common temporal trends are controlled for.

$$
\begin{array}{r}
r_{i, t}-R_{i, t}^{B}=\delta_{0}+\delta_{1} \Delta C_{i, t}+\delta_{2} A C_{i, t}+\delta_{3} P O S T_{i, t}+\delta_{4} \Delta E_{i, t}+\delta_{5} \Delta N A_{i, t}+\delta_{6} \Delta R D_{i, t}+\delta_{7} \Delta I_{i, t}+\delta_{8} \Delta D_{i, t}+ \\
\delta_{9} C_{i, t-1}+\delta_{10} L_{i, t}+\delta_{11} N F_{i, t}+\delta_{12} C_{i, t-1} * \Delta C_{i, t}+\delta_{13} L_{i, t} * \Delta C_{i, t}+\delta_{14} P O S T_{i, t} * \Delta C_{i, t}+\delta_{15} P O S T_{i, t} * \\
A C_{i, t}+\delta_{16} \Delta C_{i, t} * A C_{i, t}+\delta_{17} P O S T_{i, t} * \Delta C_{i, t} * A C_{i, t}+\text { yyearfixedeffects }+ \\
\varphi_{1} \text { yearindustryeffects }+\mu_{i, t}(2)
\end{array}
$$




\section{Macrothink}

\section{Empirical results}

\subsection{Descriptive statistics}

The descriptive statistics of the sample are provided in Table 3. The sample firms over 2007 2010 are divided into firms with an audit committee (Panel A) and firms without (Panel B). In each panel, we further analyze the statistics for data before and after establishment of an audit committee. The mean, standard deviation, max, and min statistics in Table 3 provide a general description of the sample.

The Panel A of Table 3 shows the descriptive data of firms with an audit committee. After establishment of the audit committee, the standard deviation of abnormal return $\left(r_{i, t}-R_{i, t}^{B}\right)$ declines from 0.89 to 0.79 , suggesting a decrease in variations. Panel B shows the descriptive data of paired firms (without an audit committee). Their data are divided by the treatment group's (i.e. firms with an audit committee) time of establishing an audit committee into two periods for comparison. The comparison of means shows that before establishment of an audit committee, except for the change in research and development expense $\left(\Delta R D_{t}\right)$ which reaches 0.17 , the mean differences before and after establishment of an audit committee are smaller than 0.1 across all the variables. Besides, after establishment of an audit committee, the mean differences between the treatment group and the control group are smaller than 0.07 across all the variables, suggesting high similarities between firms with an audit committee and the paired firms. In Panel C and Panel D, we compare differences between TSE-listed firms and OTC-listed firms. Among firms with an audit committee, TSE-listed firms have a mean market value $\left(\mathrm{M}_{\mathrm{t}}\right)$ of $\$ 155.73$ million, while OTC-listed firms have a mean market value of $\$ 5.72$ million. This findingconfirms that TSE-listed firms are much larger in size than OTC-listed firms.

\subsection{Correlation analysis}

To test the correlations between variables, we perform Pearson's correlation analysis. The correlation coefficient matrix is shown in Table 4. As shown in this table, all the coefficients are smaller than 0.5 , indicating absence of a serious collinearity. It should be noted that although $\left(r_{i, t}-R_{i, t}^{B}\right)$ and $A C_{t}$ are positively related, the relation is not significant. In other words, the presence of an audit committee is not positively related to abnormal return to the level of significance.

\subsection{Regression analysis}

Our extended model is aimed at testing the effect of setting up an audit committee on the value of cash holdings, that is, testing whether the use efficiency of cash holdings improves significantly after establishment of an audit committee. 
Table 3. Descriptive statistics

\begin{tabular}{|c|c|c|c|c|c|c|c|c|}
\hline \multicolumn{9}{|c|}{ Panel A:Firms with an audit committee } \\
\hline \multirow[b]{2}{*}{ Variable } & \multicolumn{4}{|c|}{ Pre-establishment $(\mathrm{N}=56)$} & \multicolumn{4}{|c|}{ Post-establishment $(\mathrm{N}=56)$} \\
\hline & Mean & SD & Min & Max & Mean & SD & Min & Max \\
\hline \multirow{2}{*}{$\begin{array}{l}r_{t}-R_{t}^{B} \\
\Delta C_{t}\end{array}$} & 0.06 & 0.89 & -1.53 & 4.70 & -0.12 & 0.79 & -1.40 & 3.99 \\
\hline & 0.03 & 0.09 & -0.13 & 0.40 & 0.00 & 0.10 & -0.29 & 0.20 \\
\hline$\Delta E_{t}$ & 0.02 & 0.16 & -0.21 & 0.75 & 0.01 & 0.23 & -0.64 & 1.20 \\
\hline$\triangle N A_{t}$ & 0.12 & 0.39 & -0.49 & 1.66 & 0.10 & 0.57 & -0.55 & 3.97 \\
\hline$\triangle R D_{t}$ & 0.01 & 0.17 & -0.49 & 1.03 & 0.08 & 0.85 & -1.83 & 5.95 \\
\hline$\Delta I_{t}$ & 0.00 & 0.00 & -0.03 & 0.01 & 0.00 & 0.00 & -0.02 & 0.02 \\
\hline$\Delta D_{t}$ & 0.01 & 0.05 & -0.06 & 0.23 & 0.00 & 0.03 & -0.06 & 0.10 \\
\hline$C_{t-1}$ & 0.12 & 0.12 & 0.00 & 0.48 & 0.17 & 0.23 & 0.00 & 1.19 \\
\hline$L_{t}$ & 0.22 & 0.17 & 0.01 & 0.65 & 0.24 & 0.20 & 0.00 & 0.79 \\
\hline$N F_{t}$ & 0.06 & 0.19 & -0.14 & 1.26 & 0.05 & 0.22 & -0.13 & 1.51 \\
\hline$M_{t}$ (Million) & 95.15 & 310.87 & 0.12 & 1743.50 & 87.72 & 271.46 & 0.43 & 1638.48 \\
\hline \multicolumn{9}{|c|}{ Panel A:Firms without an audit committee } \\
\hline \multirow[b]{2}{*}{ Variable } & \multicolumn{4}{|c|}{ Pre-establishment $(\mathrm{N}=56)$} & \multicolumn{4}{|c|}{ Post-establishment $(\mathrm{N}=56)$} \\
\hline & Mean & SD & Min & Max & Mean & SD & Min & Max \\
\hline$r_{\tau}-R_{t}^{B}$ & -0.04 & 0.56 & -1.08 & 1.92 & -0.10 & 0.56 & -2.15 & 2.12 \\
\hline$\Delta C_{t}$ & 0.02 & 0.08 & -0.32 & 0.33 & 0.00 & 0.25 & -1.72 & 0.27 \\
\hline$\Delta E_{t}$ & 0.02 & 0.10 & -0.18 & 0.37 & 0.01 & 0.14 & -0.48 & 0.76 \\
\hline$\Delta N A_{t}$ & 0.09 & 0.23 & -0.48 & 0.78 & 0.09 & 0.28 & -0.54 & 1.54 \\
\hline$\Delta R D_{t}$ & 0.18 & 0.83 & -0.05 & 5.73 & 0.01 & 0.24 & -0.88 & 1.48 \\
\hline$\Delta I_{t}$ & 0.00 & 0.00 & -0.02 & 0.01 & 0.00 & 0.00 & -0.01 & 0.00 \\
\hline$\Delta D_{t}$ & 0.00 & 0.04 & -0.08 & 0.16 & 0.01 & 0.04 & -0.06 & 0.20 \\
\hline$C_{t-1}$ & 0.11 & 0.11 & 0.00 & 0.55 & 0.17 & 0.30 & 0.00 & 2.26 \\
\hline$L_{t}$ & 0.26 & 0.18 & 0.01 & 0.73 & 0.25 & 0.17 & 0.03 & 0.77 \\
\hline$N F_{t}$ & 0.05 & 0.10 & -0.15 & 0.43 & 0.04 & 0.11 & -0.03 & 0.56 \\
\hline$M_{t}($ Million $)$ & 42.30 & 95.19 & 0.12 & 585.87 & 55.60 & 180.37 & 0.43 & 1270.74 \\
\hline
\end{tabular}




\section{Macrothink \\ Asian Journal of Finance \& Accounting \\ ISSN 1946-052X \\ 2016, Vol. 8, No. 1}

Table 3. Descriptive statistics (continued)

\begin{tabular}{|c|c|c|c|c|c|c|c|c|}
\hline \multicolumn{9}{|c|}{ Panel C:Firms with an audit committee (divided by market) } \\
\hline \multirow[b]{2}{*}{ Variable } & \multicolumn{4}{|c|}{ TSE-listed(N=64) } & \multicolumn{4}{|c|}{ OTC-listed(N=48) } \\
\hline & Mean & SD & Min & Max & Mean & SD & Min & Max \\
\hline$r_{t}-R_{t}^{B}$ & 0.04 & 0.82 & -1.53 & 4.70 & -0.12 & 0.86 & -1.40 & 3.99 \\
\hline$\Delta C_{t}$ & 0.01 & 0.08 & -0.29 & 0.25 & 0.02 & 0.12 & -0.24 & 0.40 \\
\hline$\Delta E_{t}$ & 0.05 & 0.23 & -0.36 & 1.20 & -0.03 & 0.13 & -0.64 & 0.30 \\
\hline$\Delta N A_{t}$ & 0.16 & 0.59 & -0.49 & 3.97 & 0.05 & 0.29 & -0.55 & 1.31 \\
\hline$\Delta R D_{t}$ & 0.08 & 0.81 & -1.83 & 5.95 & 0.00 & 0.03 & -0.12 & 0.04 \\
\hline$\Delta I_{t}$ & 0.00 & 0.00 & -0.03 & 0.01 & 0.00 & 0.00 & -0.02 & 0.02 \\
\hline$\Delta D_{t}$ & 0.01 & 0.05 & -0.04 & 0.23 & 0.00 & 0.03 & -0.06 & 0.09 \\
\hline$C_{t-1}$ & 0.11 & 0.12 & 0.00 & 0.48 & 0.19 & 0.24 & 0.00 & 1.19 \\
\hline$L_{t}$ & 0.23 & 0.19 & 0.01 & 0.79 & 0.23 & 0.18 & 0.00 & 0.76 \\
\hline$N F_{t}$ & 0.02 & 0.09 & -0.14 & 0.57 & 0.11 & 0.28 & 0.00 & 1.51 \\
\hline$M_{t}$ (Million) & 155.73 & 372.65 & 1.14 & 1743.50 & 5.72 & 8.88 & 0.12 & 40.89 \\
\hline \multicolumn{9}{|c|}{ Panel D:Firms without an audit committee (divided by market) } \\
\hline \multirow[b]{2}{*}{ Variable } & \multicolumn{4}{|c|}{ TSE-listed(N=64) } & \multicolumn{4}{|c|}{ OTC-listed(N=48) } \\
\hline & Mean & SD & Min & Max & Mean & SD & Min & Max \\
\hline$r_{t}-R_{t}^{B}$ & 0.00 & 0.50 & -1.08 & 1.92 & -0.16 & 0.63 & -2.15 & 2.12 \\
\hline$\Delta C_{t}$ & 0.03 & 0.07 & -0.11 & 0.33 & -0.01 & 0.27 & -1.72 & 0.27 \\
\hline$\Delta E_{t}$ & 0.01 & 0.08 & -0.18 & 0.32 & 0.03 & 0.17 & -0.48 & 0.76 \\
\hline$\Delta N A_{t}$ & 0.09 & 0.21 & -0.54 & 0.78 & 0.09 & 0.31 & -0.48 & 1.54 \\
\hline$\Delta R D_{t}$ & 0.15 & 0.78 & -0.27 & 5.73 & 0.02 & 0.26 & -0.88 & 1.48 \\
\hline$\Delta I_{t}$ & 0.00 & 0.00 & -0.01 & 0.01 & 0.00 & 0.00 & -0.02 & 0.01 \\
\hline$\Delta D_{t}$ & 0.00 & 0.03 & -0.08 & 0.14 & 0.01 & 0.05 & -0.06 & 0.20 \\
\hline$C_{t-1}$ & 0.11 & 0.10 & 0.00 & 0.50 & 0.18 & 0.33 & 0.01 & 2.26 \\
\hline$L_{t}$ & 0.25 & 0.18 & 0.01 & 0.77 & 0.26 & 0.17 & 0.03 & 0.73 \\
\hline$N F_{t}$ & 0.03 & 0.09 & -0.15 & 0.43 & 0.06 & 0.12 & -0.03 & 0.56 \\
\hline$M_{t}$ (Million) & 82.15 & 183.35 & 1.14 & 1270.73 & 4.67 & 7.37 & 0.12 & 35.38 \\
\hline
\end{tabular}


Table 4. Correlation coefficient matrix

\begin{tabular}{|c|c|c|c|c|c|c|c|c|c|c|c|c|}
\hline Variable & $r_{t}-R_{t}^{B}$ & $\Delta C_{t}$ & $\mathrm{POST}_{\mathrm{t}}$ & $\mathrm{AC}_{\mathrm{t}}$ & $\Delta E_{t}$ & $\Delta N A_{t}$ & $\Delta R D_{t}$ & $\Delta I_{t}$ & $\Delta D_{t}$ & $C_{t-1}$ & $L_{t}$ & $N F_{t}$ \\
\hline$\overline{r_{t}-R_{t}^{B}}$ & 1 & & & & & & & & & & & \\
\hline$\Delta C_{t}$ & $0.217^{* * * *}$ & 1 & & & & & & & & & & \\
\hline POST $_{t}$ & -0.088 & -0.108 & 1 & & & & & & & & & \\
\hline $\mathrm{AC}_{\mathrm{t}}$ & 0.029 & 0.013 & 0 & 1 & & & & & & & & \\
\hline$\Delta E_{t}$ & $0.293^{* * * *}$ & $-0.188^{* * *}$ & -0.024 & -0.001 & 1 & & & & & & & \\
\hline$\Delta N A_{t}$ & $0.253^{* * * *}$ & $-0.167 *$ & -0.015 & 0.032 & $0.407^{* * * *}$ & 1 & & & & & & \\
\hline$\Delta R D_{t}$ & 0.119 & $0.178^{* *}$ & -0.042 & -0.042 & 0.030 & $0.461 * * *$ & 1 & & & & & \\
\hline$\Delta I_{t}$ & $-0.142^{*}$ & 0.071 & -0.011 & 0.044 & $-0.255^{* * *}$ & -0.026 & -0.061 & 1 & & & & \\
\hline$\Delta D_{t}$ & $0.426^{* * * *}$ & 0.112 & -0.013 & 0.019 & $0.480^{* * * *}$ & $0.325^{* * *}$ & $-0.140^{*}$ & $-0.149^{*}$ & 1 & & & \\
\hline$C_{t-1}$ & -0.121 & $-0.597 * * *$ & $0.141^{*}$ & 0.012 & $0.268^{* * * *}$ & $0.175^{* *}$ & -0.096 & $-0.181^{* *}$ & 0.074 & 1 & & \\
\hline$L_{t}$ & $-0.181 * *$ & 0.061 & 0.017 & -0.062 & $-0.190^{* *}$ & -0.090 & -0.041 & 0.045 & $-0.212^{* *}$ & -0.049 & 1 & \\
\hline$N F_{t}$ & 0.06 & $0.140^{*}$ & -0.01 & 0.039 & 0.036 & $0.266 * * *$ & -0.079 & 0.015 & $0.187^{* *}$ & -0.028 & -0.014 & 1 \\
\hline
\end{tabular}

Notes:

1. *** $\mathrm{p}<0.01, * * \mathrm{p}<0.05, * \mathrm{p}<0.1$

2. Variable definition: $r_{t}-R_{t}^{B}$ denotes abnormal returns; $\Delta C_{t}$ denotes change in cash and cash equivalents divided by market value of the previous period; $P O S T_{t}$ is a dummy variable where 1 indicates the year when an audit committee is established or the next year, and 0 indicates other periods of time; $A C_{t}$ is a dummy variable where 1 indicates presence of an audit committee and 0 indicates absence of an audit committee; $\Delta E_{t}$ denotes earnings from extraordinary items and interest divided by market value of the previous period; $\Delta N A_{t}$ denotes change in assets minus cash divided by market value of the previous period; $\Delta R D_{t}$ denotes change in research and development expense divided by market value of the previous period; $\Delta I_{t}$ denotes change in interest expense divided by market value of the previous period; $\Delta D_{t}$ denotes change in dividends on common shares divided by market value of the previous period; $C_{t-1}$ denotes the sum of cash and cash equivalent over yeart-1; $L_{t}$ denotes total debt divided by the sum of market value of equity and total debt; $N F_{t}$ denotes the total equity issuance minus repurchases plus debt issuance minus debt redemption.

In Table 5, regression equation (1) first tests the effect of setting up an audit committee among all the 112 firms with an audit committee during 2007 2010. This test is intended to find if an additional dollar held can create a value higher than a dollar in the presence of an audit committee. In other words, it is to test the use efficiency of cash holdings. It should be noted in Table 5 that among all the sample firms, the product term of change in cash and post-establishment $\left(\triangle \mathrm{C}_{\mathrm{t}}{ }^{*} P O S T_{\mathrm{t}}\right)$ is positively related to abnormal return $\left(r_{i, t}-R_{i, t}^{B}\right)$. The coefficient is 2.034 and $p$-value $=0.182$. The coefficient is not significant. This explains that among firms with an audit committee, there has not been a significant increase in the marginal value of one dollar cash since an audit committee was established.

To control the effect of common temporal trends on the value of cash holdings, we build a sample of firms without an audit committee to pair with firms with an audit committee (treatment group). The firms in this paired sample are selected by industry, market, year, and market value. This paired sample is then used as the control group. Each group consists of 112 firms. Using DID method, we evaluate the effect of the policy of audit committee establishment on the value of cash holdings. The result of regression equation (2) shows that the product term of change in cash, presence of an audit committee, and post-establishment of 
an audit committee $\left(\triangle C_{t} * A C_{t} * P O S T_{t}\right)$ is positively related to abnormal return $\left(r_{i, t}-R_{i, t}^{B}\right)$. The coefficient is 0.264 , and p-value is 0.891 . The coefficient is not significant. Findings from regression equations (1) which tests the effect of an audit committee on the value of cash holdings for firms without an audit committee and regression equation (2) where the effect of temporal trends is controlled all suggest that setting up an audit committee cannot lead to a significant increase in the value of cash holdings and a reduction of agency costs. Hence, $\mathrm{H} 1$ is not supported.

In further observation of the relations between other control variables and abnormal return $\left(r_{i, t}-R_{i, t}^{B}\right)$ in Equation (1) and Equation (2),we find that the coefficients on $\Delta N A_{t}$ are 0.757 with $\mathrm{p}$-value $=0.005$ and 0.355 with $\mathrm{p}$-value $=0.033$ respectively; the coefficients on $\Delta D_{t}$ are 8.135 with $\mathrm{p}$-value $<0.000$ and 6.334 with $\mathrm{p}$-value $<0.000$. In other words, both change in assets minus cash and cash equivalents and change in dividends on common shares are positively related to abnormal return to the level of significance. Consistent results are obtained from Equation (1) and Equation (2). The coefficients on $\Delta I_{t}$ are -56.540 with p-value $=0.001$ and -22.930 with $p$-value $=0.032$; the coefficients on $L_{t}$ are -0.713 with $\mathrm{p}$-value $=0.075$ and -0.732 with $\mathrm{p}$-value $=0.004$, suggesting that change in interest expense and leverage are negatively related to abnormal return to the level of significance. Consistent findings are obtained from Equation (1) and Equation (2).

To further examine if the effect of an audit committee on the value of cash holdings varies by market, we divide the sample by market into TSE-listed firms and OTC-listed firms. Using DID method, we evaluate the association between an audit committee and the value of cash holdings in the two markets. As shown in Table 6, the product term of change in cash, post-establishment of an audit committee, and presence of an audit committee $\left(\Delta C_{t} * \operatorname{POST}_{t} * A \mathrm{C}_{t}\right)$ is positively related to abnormal return $\left(r_{i, t}-R_{i, t}^{B}\right)$ among TSE-listed firms, and the relation is significant (coefficient=6.657, p-value $=0.060$ ). This finding indicates that after the effect of temporal trends is controlled for, setting up an audit committee can lead to a significant rise of the value of cash holdings in TSE-listed firms, allowing the firms to reduce their agency costs.

Among OTC-listed firms, the product term of change in cash, post-establishment of an audit committee and presence of an audit committee $\left(\triangle C_{t} * P O S T_{t} * A C_{t}\right)$ is negatively related to abnormal return $\left(r_{i, t}-R_{i, t}^{B}\right)$, and the relation is significant (coefficient=-6.105, p-value=0.046). This finding suggests that after the effect of temporal trends is controlled for, the value of cash holdings in OTC-listed firms declines significantly, and the expected reduction of agency costs cannot be achieved. This finding supports our second hypothesis which proposes that the presence of an audit committee can generate a higher increase in the marginal value of cash holdings for TSE-listed firms than for OTC-listed ones. In the OTC market, individual investors account for a higher proportion compared to institutional investors. In addition, stock liquidity is lower, and the compliance cost for firms is higher. 


\section{Macrothink}

These are the reasons why setting up an audit committee contrarily leads to a decline in the value of cash holdings. As to the relations between control variables and abnormal return, the relation between the change in dividends on common shares and abnormal return $\left(r_{i, t}-R_{i, t}^{B}\right)$ is consistent across TSE-listed and OTC-listed firms. The coefficients on $\Delta D_{t}$ among TSE-listed firms and OTC-listed firms are 4.103 with p-value $<0.052$ and 7.019 with p-value $<0.001$, suggesting that change in dividends on common shares is significantly and positively related to abnormal return.

Table 5. The effect of setting up an audit committee on the values of cash holdings

\begin{tabular}{|c|c|c|c|c|}
\hline \multirow[b]{3}{*}{ Independent variable } & \multicolumn{4}{|c|}{ Dependent variable $=r_{t}-R_{t}^{B}$} \\
\hline & \multicolumn{2}{|c|}{ (1)Before pairing } & \multicolumn{2}{|c|}{ (2)After pairing } \\
\hline & Coefficient & $\mathrm{p}$-values & Coefficient & p-values \\
\hline Intercept & 0.580 & 0.286 & 0.057 & 0.816 \\
\hline$\Delta C_{t}$ & -2.323 & 0.237 & 0.902 & 0.457 \\
\hline $\operatorname{PosT}_{t}$ & -0.043 & 0.821 & -0.173 & 0.221 \\
\hline $\mathrm{AC}_{\mathrm{t}}$ & & & 0.012 & 0.921 \\
\hline$\Delta E_{t}$ & 0.263 & 0.542 & 0.329 & 0.310 \\
\hline$\Delta N A_{t}$ & $0.757 * * *$ & 0.005 & $0.355 * *$ & 0.033 \\
\hline$\Delta R D_{t}$ & $-0.532 * * *$ & 0.006 & -0.049 & 0.628 \\
\hline$\Delta I_{t}$ & $-56.540 * * *$ & 0.001 & $-22.93 * *$ & 0.032 \\
\hline$\Delta D_{t}$ & $8.135 * * *$ & 0.000 & $6.334 * * *$ & 0.000 \\
\hline$C_{t-1}$ & -0.473 & 0.281 & -0.358 & 0.252 \\
\hline$L_{t}$ & $-0.713 *$ & 0.075 & $-0.732 * * *$ & 0.004 \\
\hline$N F_{t}$ & -0.409 & 0.325 & -0.312 & 0.306 \\
\hline$\Delta C_{t}^{*} C_{t-1}$ & -1.973 & 0.570 & -0.430 & 0.470 \\
\hline$L_{t} * \Delta C_{t}$ & $11.040 * * *$ & 0.005 & 2.657 & 0.320 \\
\hline $\operatorname{PosT}_{\mathrm{t}} * \Delta C_{t}$ & 2.034 & 0.182 & 0.309 & 0.826 \\
\hline $\operatorname{PoST}_{\mathrm{t}} * \mathrm{AC}_{\mathrm{t}}$ & & & 0.0475 & 0.777 \\
\hline$\Delta C_{t} * \mathrm{AC}_{\mathrm{t}}$ & & & -1.064 & 0.455 \\
\hline$\Delta C_{t} * \operatorname{POST}_{\mathrm{t}} * \mathrm{AC}_{\mathrm{t}}$ & & & 0.264 & 0.891 \\
\hline Adjusted $R^{2}$ & 0.443 & & 0.310 & \\
\hline $\mathrm{N}$ & 112 & & 224 & \\
\hline
\end{tabular}

Notes:

1. $* * * \mathrm{p}<0.01, * * \mathrm{p}<0.05, * \mathrm{p}<0.1$

2. Variable definition: $r_{t}-R_{t}^{B}$ denotes abnormal returns; $\Delta C_{t}$ denotes change in cash and cash equivalents divided by market value of the previous period;POST $t$ is a dummy variable where 1 indicates the year when an audit committee is established or the next year, and 0 indicates other periods of time; $A C_{t}$ is a dummy variable where 1 indicates presence of an audit committee and 0 indicates absence of an audit committee; $\Delta E_{t}$ denotes 
earnings from extraordinary items and interest divided by market value of the previous period; $\Delta N A_{t}$ denotes change in assets minus cash divided by market value of the previous period; $\Delta R D_{t}$ denotes change in research and development expense divided by market value of the previous period; $\Delta I_{t}$ denotes change in interest expense divided by market value of the previous period; $\Delta D_{t}$ denotes change in dividends on common shares divided by market value of the previous period; $C_{t-1}$ denotes the sum of cash and cash equivalent over year $t-1$; $L_{t}$ denotes total debt divided by the sum of market value of equity and total debt; $N F_{t}$ denotes the total equity issuance minus repurchases plus debt issuance minus debt redemption.

3. $\mathrm{N}$ denotes the number of observations.

Table 6. The effect of setting up an audit committee after pairing (by market)

\begin{tabular}{|c|c|c|c|c|}
\hline \multirow[b]{3}{*}{ Independent variable } & \multicolumn{4}{|c|}{ Dependent variable $=r_{t}-R_{t}^{B}$} \\
\hline & \multicolumn{2}{|c|}{ TSE-listed firms } & \multicolumn{2}{|c|}{ OTC-listed firms } \\
\hline & Coefficient & p-values & Coefficient & p-values \\
\hline Intercept & 0.082 & 0.817 & $1.603 * * *$ & 0.001 \\
\hline$\Delta C_{t}$ & 2.508 & 0.249 & -0.479 & 0.796 \\
\hline $\operatorname{POST}_{t}$ & 0.026 & 0.894 & -0.264 & 0.294 \\
\hline $\mathrm{AC}_{\mathrm{t}}$ & 0.100 & 0.543 & -0.181 & 0.396 \\
\hline$\Delta E_{t}$ & 0.395 & 0.290 & -0.515 & 0.525 \\
\hline$\Delta N A_{t}$ & $0.449 * *$ & 0.029 & 0.649 & 0.115 \\
\hline$\Delta R D_{t}$ & $-0.216 * *$ & 0.089 & -0.393 & 0.408 \\
\hline$\Delta I_{t}$ & $-58.170 * * *$ & 0.000 & -0.103 & 0.996 \\
\hline$\Delta D_{t}$ & $4.103 * *$ & 0.052 & $7.09 * * *$ & 0.001 \\
\hline$C_{t-1}$ & -0.150 & 0.819 & -0.492 & 0.259 \\
\hline$L_{t}$ & -0.549 & 0.140 & $-0.887 *$ & 0.078 \\
\hline$N F_{t}$ & -0.176 & 0.827 & -0.626 & 0.137 \\
\hline$\Delta C_{t} * C_{t-1}$ & 5.776 & 0.333 & -0.873 & 0.332 \\
\hline$L_{t} * \Delta C_{t}$ & 0.923 & 0.840 & -4.876 & 0.289 \\
\hline $\mathrm{POST}_{\mathrm{t}} * \Delta C_{t}$ & -2.082 & 0.396 & 3.375 & 0.134 \\
\hline $\mathrm{POST}_{\mathrm{t}} * \mathrm{AC}_{\mathrm{t}}$ & -0.110 & 0.627 & 0.3170 & 0.271 \\
\hline$\Delta C_{t} * \mathrm{AC}_{\mathrm{t}}$ & $-5.498 * *$ & 0.025 & $4.587 *$ & 0.059 \\
\hline$\Delta C_{t} * \operatorname{PoST}_{\mathrm{t}} * \mathrm{AC}_{\mathrm{t}}$ & $6.657 *$ & 0.060 & $-6.105 * *$ & 0.046 \\
\hline Adjusted $R^{2}$ & 0.443 & & 0.347 & \\
\hline $\mathrm{N}$ & 128 & & 96 & \\
\hline
\end{tabular}

Notes:

1. $* * * \mathrm{p}<0.01, * * \mathrm{p}<0.05, * \mathrm{p}<0.1$

2. Variable definition: $r_{t}-R_{t}^{B}$ denotes abnormal returns; $\Delta C_{t}$ denotes change in cash and cash equivalents divided by market value of the previous period;POST $t$ is a dummy variable where 1 indicates the year when an audit committee is established or the next year, and 0 indicates other periods of time; $A C_{t}$ is a dummy variable where 1 indicates presence of an audit committee and 0 indicates absence of an audit committee; $\Delta E_{t}$ denotes earnings from extraordinary items and interest divided by market value of the previous period; $\Delta N A_{t}$ denotes change in assets minus cash divided by market value of the previous period; $\Delta R D_{t}$ denotes change in research and development expense divided by market value of the previous period; $\Delta I_{t}$ denotes change in interest 
expense divided by market value of the previous period; $\Delta D_{t}$ denotes change in dividends on common shares divided by market value of the previous period; $C_{t-1}$ denotes the sum of cash and cash equivalent over year $t-1$; $L_{t}$ denotes total debt divided by the sum of market value of equity and total debt; $N F_{t}$ denotes the total equity issuance minus repurchases plus debt issuance minus debt redemption.

3. $\mathrm{N}$ denotes the number of observations.

4. TSE-listed firms: Firms are required to have an actual paid-in capital exceeding NT\$600 million; OTC-listed firms: Firms are required to have an actual paid-in capital exceeding NT\$50 million.

\section{Conclusions and suggestions}

The existing corporate governance systems can be classified into the single-track Anglo-Saxon system based on the independent board system with an audit committee and the two-tiered Continental system based on the supervisor system. Despite mixed conclusions about the monitoring effectiveness of the two major systems, there is a trend toward establishment of an audit committee in nations using a dual-track system. The requirement of setting up an audit committee is mainly intended to reinforce corporate governance and increase the quality and reliability of financial reporting. Previous research has focused primarily on the effect of setting up an audit committee on the quality of financial statements and seldom examined from a broader perspective if the presence of an audit committee can lead to a higher firm performance due to improvement of the corporate governance environment, In this study, we focus on the improvement of the agency problem through establishment of an audit committee. We examine if setting up an audit committee can lead to a rise of the value of cash holdings. We draw upon a sample of publicly listed firms with an audit committee in Taiwan during 2007 2010 to examine if the use efficiency of cash holdings significantly improves after establishment of an audit committee, without discounting the marginal value of cash holdings. Empirical findings from the test with only firms with an audit committee and the test with two groups of firms based on a DID approach all indicate that the use efficiency of cash holdings does not improve significantly after an audit committee is established.

We further divide the sample by market into TSE-listed firms and OTC-listed firms for regression analysis. We obtain completely different findings from the two markets. From TSE-listed firms, we find that the presence of an audit committee can contribute to a higher marginal value of cash holdings and mitigate the effect of agency costs on firm efficiency. From OTC-listed firms, we find that the presence of an audit committee will contrarily reduce the marginal value of cash holdings. This finding suggests that if a market has a lower liquidity and a lower ratio of institutional investors, the market will receive less attention from investors and thus have a higher degree of information asymmetry. With the weakening of external oversight, the benefits of setting up an audit committee cannot be reflected upon the efficiency of cash holdings. Besides, OTC-listed firms are smaller, so the cost of complying with regulations regarding establishment of an audit committee will be higher for them. As a result, these firms may suffer adverse effects before they can reap the benefits of adopting the audit committee system.

Regarding to the burden caused by SOX requirements on small firms, most of scholars have made several suggestions, including alleviation of the burden and relaxation of format and 
content requirements for financial reports. Rose suggests that it is faster to alleviate the burden on small firms than to increase the benefits of going public for them. In recent years, the legislature and authorities in Taiwan have made several amendments to the Company Act and the Securities and Exchange Act to promote corporate governance, increase the reliability of financial reports, and facilitate smooth operations of capital markets. However, costs and benefits should be simultaneously considered while making a decision over establishment of a new system. If the compliance cost exceeds the benefits, the authority concerned is advised to adjust their policy based on empirical evidence. For smaller firms and markets with lower liquidity, direct introduction of foreign governance systems is not advisable. Instead, the authority concerned should tailor-make a governance system that can effectively exert its oversight functions in small firms while ensuring that the monitoring effects are greater than the costs of compliance. This system better conforms to the conditions and development of corporate governance in our nation.

Our empirical evidence shows that the authority concerned in Taiwan has taken into account the effect of firm size when introducing the new system. In the beginning, the law prescribes that starting 2006, all publicly listed firms shall establish an audit committee or a supervisor. Later, it is regulated that starting in 2013, it is mandatory for all financial institutions and publicly listed firms in non-financial sectors with an actual paid-in capital exceeding NT\$50 billion to establish an audit committee. At the end of 2013, the authority concerned resolved to implement the audit committee system in stages, requiring all publicly listed firms with a capital exceeding NT $\$ 10$ billion shall establish an audit committee immediately, and those with a capital exceeding NT $\$ 2$ billion shall comply with the requirement by $2017^{5}$. The development of these requirements manifests that the audit committee system has been progressively implemented in Taiwan with consideration of firm size. In our study, we find that most firms with an audit committee have implemented the system voluntarily (about 90\%). Hence, we suggest firms planning to set up an audit committee not under a mandatory compliance requirement should also evaluate the compatibility of their internal and external environments, so as to avoid being negatively impacted by adoption of the system before it pays off.

\section{Note}

1. The importance of corporate governance can be extended to other governance areas, including quality of earnings and accruals (Baxter and Cotter, 2009; Kent et al., 2010), CEO dismissal (Lau et al., 2009); information disclosure (Nelson et al., 2010), audit fees (Griffin et al., 2010; Bliss, 2011), and reorganization (Owen et al., 2010).

2. Data of ratio of individual investment are obtained from TEJ.

3. Chip distribution data are obtained from TEJ.

4. In order to comply with the government's economic or social regulations, businesses need to make substantial changes and follow a series of complicated application, certification or administrative verification procedures to report their compliance. These procedures often cause a tremendous stress on firms. The costs of meeting these requirements are called the compliance costs (OECD, 2003)

5. Financial Supervisory Commission Order Cheng-Fa No:10200531121 


\section{References}

Abbott, L. J., Parker, S. (2000). Auditor selection and audit committee characteristics.Auditing: A Journal of Practice \& Theory, 19(2), 47-66. http://dx.doi.org/10.2308/aud.2000.19.2.47

Abbott, L. J., Parker, S.,Peters, G. F., Raghunandan, K. (2003).The association between audit committee characteristics and audit fees.Auditing: A Journal of Practice \& Theory,22(2), 17-32. http://dx.doi.org/10.2308/aud.2003.22.2.17

Akhigbe, A., Martin, A. D. (2006). Valuation impact of Sarbanes-Oxley: Evidence from disclosure and governance within the financial services industry. Journal of Banking and Finance, 30(3), 989-1006.http://dx.doi.org/10.1016/j.jbankfin.2005.06.002

Ball, R., Kothari, S. P.,\& Robin, A. (2000). The effect of institutional factors on properties on accounting earnings: International evidence.Journal ofAccounting and Economics,29(1), 1-51.http://dx.doi.org/10.1016/S0165-4101(00)00012-4

Baxter, P., Cotter, J. (2009). Audit committees and earnings quality.Accounting and Finance,49(2), 267-290.http://dx.doi.org/10.1111/j.1467-629X.2008.00290.x

Bedard, J., Chtourou, S. M., \&Courteau, L.(2004). The effect of audit committee expertise, independence, and activity on aggressive earnings management.Auditing: A Journal of Practice \& Theory, 23(2), 13-35.http://dx.doi.org/10.2308/aud.2004.23.2.13

Berle, A. A.,\& Means, G. C. (1932).The Modern Corporation and Private Property. MacMillan Publishing Co., New York. http://dx.doi.org/10.1111/j.1467-9299.1934.tb01905.x

Bernstein, P. L. (1987). Liquidity, stock markets, and market makers.Financial Management, 16(2), 54-62. http://dx.doi.org/10.2307/3666004

Bliss, M. A. (2011). Does CEO duality constrain board independence? Some evidence from audit pricing.Accounting and Finance,51(2), 361-380.http://dx.doi.org/10.1111/j.1467-629X.2010.00360.x

Block, S. B. (2004). The latest movement to going private: an empirical study. Journal of Applied Finance, 14, 6-44.http://dx.doi.org/10.1007/BF02751643

Blundell, J.,\& Robinson, C. (2000).Regulation without the State...The Debate Continues.Institute of Economic Affairs, London.http://dx.doi.org/10.1111/j.1468-0270.1996.tb00532.x

Bull, I., \&Sharp, F. C. (1989). Advising clients on Treadway audit committee recommendations.Journal of Accountancy,167(2), 46-52.

Chittenden, F., Kauser, S., \&Poutzouris, P. (2002). Regulatory burdens of small business: A $\begin{array}{lllll}\text { literature } & \text { review. } & \text { Assessed } & 2 & \text { Jun }\end{array}$ http://www.sbs.gov.uk/content/analytical/research/Regulation-Report.pdf.

Chittenden, F., Kauser, S.,\&Poutzouris, P. (2003).Tax regulation and small business in the 


\section{MInstitute Macrothink $^{\text {Int }}$}

Asian Journal of Finance \& Accounting

ISSN 1946-052X

2016, Vol. 8, No. 1

USA, UK, Australia and New Zealand.International Small Business Journal,21(1), 93-115.http://dx.doi.org/10.1177/0266242603021001244

Chui, A. C. W., \&Wei, K. C. J. (1998). Book-to-market, firm size, and the turn-of-the-year effect: Evidence from Pacific-Basin emerging markets. Pacific-Basin Finance Journal,41(6), 275-293.http://dx.doi.org/10.1016/S0927-538X(98)00013-4

Cohen., J. R., Udi, H., Ganesh, K., \&Arnold, M. W. (2014). The effect of audit committee industry expertise on monitoring the financial reporting process.The Accounting Review,89(1), 243-273.http://dx.doi.org/10.2308/accr-50585

Cooper. S. K., Groth, J. C., \&Avera, W. E. (1985). Liquidity, exchange listing, and common stock performance.Journal of Economics and Business, 37(1), 19-33.http://dx.doi.org/10.1016/0148-6195(85)90003-7

DiGabriele, J. (2008). The Sarbanes-Oxley Act and the private company discount: An empirical investigation. Critical Perspectives on Accounting,19(8), 1105-1121.http://dx.doi.org/10.1016/j.cpa.2007.03.005

Dittmar, A., \&Mahrt-Smith, J.(2007).Corporate governance and the value of cash holdings.Journal of Financial Economics,83(3), 599-634.http://dx.doi.org/10.1016/j.jfineco.2005.12.006

Fama, E. F. (1980). Agency problems and the theory of the firm. The Journal of Political Economy, 88(2), 288-307.http://dx.doi.org/10.1086/260866

Fama, E. F.,\&Jensen, M.C. (1983).Separation of ownership and control.Journal ofLaw and Economics, 26(2),301-325.http://dx.doi.org/10.1086/467037

Fama, E. F.,\& Jensen, M. C. (1983).Agency problems and residual claims.Journal of Law and Economics,26(2), 327-349.http://dx.doi.org/10.1086/467038

Fama, E., \&French, K. (1993).Common risk factors in the returns on stocks and bonds.Journal of Financial Economics, 3-56.http://dx.doi.org/10.1016/0304-405X(93)90023-5

Fang, V. W., Noe, T. H., \&Tice, S. (2009). Stock market liquidity and firm value.Journal of Financial Economics, 94(1),150-169.http://dx.doi.org/10.1016/j.jfineco.2008.08.007

Faulkender, M., \&Wang, R. (2006).Corporate financial policy and the value ofcash.Journal of Finance, 61(4), 1957-1990.http://dx.doi.org/10.1111/j.1540-6261.2006.00894.x

Felo, A. J., Srinivasany, K., \&Solieri, S. A. (2003).Audit committee characteristics and the perceived quality of financial reporting: An empirical analysis.Working paper.

Fraser, D. R., \&Groth, J. C. (1985). Listing and the liquidity of bank stocks.Journal of Bank Research, 6, 136-144.

Griffin, P. A., Lont, D. H., \&Sun, Y.(2010). Agency problems and audit fees: Further tests of the free cash flow hypothesis. Accounting and Finance, 50(2), 
321-350.http://dx.doi.org/10.1111/j.1467-629X.2009.00327.x

Grossman, S. (1981). The information role of warranties and private disclosure about product quality.Journal of Law and Economics,24(3), 461-483.http://dx.doi.org/10.1086/466995

Huang, C. L., Chen, W. J., \&Lu, K. C. (2014). The monitoring effect of information disclosure: Institutional and retail investors. International Journal of Information and Management Sciences, 25(S), 197-214.http://dx.doi.org/10.6186/IJIMS.2014.25.3.1

Huang, H. H. (2013). A Comparison of market performance: Taiwan Stock Exchange and R.O.C. Over-the-counter Securities Exchange. National Taiwan University Law Journal, 42(S), 1109 - 1145. http://dx.doi.org/10.6199/NTULJ.2013.42.SP.09

Hasbrouck, J., \&Schwartz, R. A. (1988).Liquidity and execution costs in equity markets.The Journal of Portfolio Management, 14(3), 10-16.http://dx.doi.org/10.3905/jpm.1988.409160

Holmstrom, B., \&Kaplan, S. (2003). The state of U.S. corporate governance: What's right and what's wrong? Journal of Applied Corporate Finance,15(3), 8-20.http://dx.doi.org/10.1111/j.1745-6622.2003.tb00457.x

Hsu, W. H. (2014). Can audit committee improve earnings quality more than the supervisors in Taiwan? NTU Management Review, 24(S1), 203-232.http://dx.doi.org/10.6226/NTURM2014.JUN.R11002

Jensen, M. C., \&Meckling, W. H. (1976). Theory of the firm: managerial behavior, agency costs \& ownership structure. Journal of Financial Economics,3(4), 305-360.http://dx.doi.org/10.1016/0304-405X(76)90026-X

Kent, P., Routledge, J.,\&Stewart, J. (2010).Innate and discretionary accrual quality and corporate governance.Accounting and Finance,50(1), 171-195.http://dx.doi.org/10.1111/j.1467-629X.2009.00321.x

Keynes, J. M. (1936). The General Theory of Employment, Interest, and Money.Macmillan: London.

Koehn, L,\& Del Vecchio, S. (2004). Ripple effects of the Sarbanes-Oxley Act.The CPA Journal, 74(2), 36-40.http://dx.doi.org/10.9774/GLEAF.4700.2005.wi.00005

La Porta, R., Lopez-De-Silanes, F., \&Shleifer, A. (2002). Government ownership of banks.The Journal of Finance,57(1), 265-301.http://dx.doi.org/10.1111/1540-6261.00422

Lau, J., Sinnadurai, P. Wright, S. (2009). Corporate governance and chief executive officer dismissal following poor performance: Australian evidence. Accounting and Finance, 49(1), 161-182.http://dx.doi.org/10.1111/j.1467-629X.2008.00278.x

Marsh, T., Rock, K. (1986). Exchange listing and liquidity: A comparison of the American Stock Exchange with the NASDAQ National Market System. American Stock Exchange Transaction Data Research Project \#2.

Maug, E. (1998). Large shareholders as monitors: Is there a trade-off between liquidity and 
control? Journal of Finance,53(1), 65-98. http://dx.doi.org/10.1111/0022-1082.35053

Michaelis, C., Smith, K., Richards, S.(2001). Regular survey of small business, opinions: First $\quad$ survey - $\quad$ Final report. http://www.sbs.gov.uk/content/analytical/research/omnibussurvey1.pdf.

Milgrom, P. R.(1981). Good news and bad news: representation theorems and applications. The Bell Journal of Economics,12(2), 380-391.http://dx.doi.org/10.2307/3003562

Myers, S. C.,\&Rajan, R. G. (1998).The paradox of liquidity.Quarterly Journal of Economics,113(3), 733-771.http://dx.doi.org/10.1162/003355398555739

Menon, K.,\& Williams, D. J.(1994).The use of audit committee for monitoring.Journal of Accounting and Public Policy,13(2), 121-139.http://dx.doi.org/10.1016/0278-4254(94)90016-7

Mount, I. (2005). Death of the IPO dream.Fortune Small Business, 15, 3-6.

Naidu, G. N.,\& Rozeff, M. S. (1994). Volume, volatility, liquidity and efficiency of the Singapore stock exchange before and after automation.Pacific-Basin Finance Journal, 2(1), 23-42.http://dx.doi.org/10.1016/0927-538X(94)90027-2

Nelson, J., Gallery, G.,\& Percy, M. (2010).Role of corporate governance in mitigating the selective disclosure of executive stock option information.Accounting and Finance,50(3), 685-717. http://dx.doi.org/10.1111/j.1467-629X.2009.00339.x

Oviatt, B. M. (1988). Agency and transaction cost perspectives on the manager-shareholder relationship: Incentives for congruent interests. The Academy of Management Review,13(2), 214-225. http://dx.doi.org/10.5465/AMR.1988.4306868

Owen, S., Shi, L.,\&Yawson, A. (2010).Diverstitures, wealth effects and corporate governance.Accounting and Finance,50(2), 389-415. http://dx.doi.org/10.1111/j.1467-629X.2009.00332.x

Pinkowitz, L., Stulz, R.,\&Williamson, R. (2006).Does the contribution of corporate cash holdings and dividends to firm value depend on governance? A cross-country analysis.Journal of Finance, $61(6)$, 2725-2751.http://dx.doi.org/10.1111/j.1540-6261.2006.01003.x

Pound, J. (1988). Proxy Contests and the Efficiency of Shareholder Oversight.Journal of Financial Economics,20, 237-265.http://dx.doi.org/10.1016/0304-405X(88)90046-3

Spence, D.B. (2001). The shadow of the rational polluter: Rethinking the role of rational actor models in environmental law. California Law Review,89(4), 917-998.http://dx.doi.org/10.2307/3481289

Verrecchia., R. E. (1983). Discretionary disclosure. Journal of Accounting and Economics,5(Jan), 179-194.http://dx.doi.org/10.1016/0165-4101(83)90011-3

Williamson, O. E. (1983). Organization form, residual claimants and corporate 


\section{Macrothink}

control.Journal of Law and Economics,26(2), 351-366.http://dx.doi.org/10.1086/467039

Wild, J. J. (1996).The audit committee and earnings quality.Journal of Accounting, Auditing and Finance,11(Apr), 247-276.

Zahra, S. A., \&Pearce II, J. A. (1989). Boards of directors and corporate financial performance: A review and integrated model. Journal of Management, 15(2), 291-334.http://dx.doi.org/10.1177/014920638901500208

\section{Copyright Disclaimer}

Copyright for this article is retained by the author(s), with first publication rights granted to the journal.

This is an open-access article distributed under the terms and conditions of the Creative Commons Attribution license (http://creativecommons.org/licenses/by/3.0/). 